\title{
EVALUASI PEMANFAATAN LABORATORIUM PADA DIKLAT PENGENDALI HAMA DAN PENYAKIT IKAN DI BALAI DIKLAT APARATUR KEMENTERIAN KELAUTAN DAN PERIKANAN
}

\author{
Fajar Nugroho \\ Balai Diklat Aparatur, Kementerian Kelautan dan Perikanan \\ Jl. Raya 2 Sukamandi Ciasem, Subang, 41256, Jawa Barat, Indonesia \\ Email: fajarfathi2010@gmail.com
}

\begin{abstract}
Abstrak
Keberadaan laboratorium menjadi hal yang penting dalam pelaksanaan Diklat Pengendali Hama dan Penyakit Ikan (PHPI) oleh karena itu Balai Diklat Aparatur (BDA) Kementerian Kelautan dan Perikanan (KKP) bekerja sama dengan Stasiun Karantina Ikan Kelas II Cirebon pada tahun 2014 membangun laboratorium uji karantina ikan di lingkungan kampus BDA KKP. Kajian ini bertujuan untuk mengevaluasi pemanfaatan laboratorium Diklat PHPI dengan mengukur perubahan kepuasan peserta terhadap ketersediaan media pembelajaran dan kelengkapan fasilitas belajar mengajar, nilai hasil belajar, peningkatan pengetahuan dan keterampilan peserta sebelum dan setelah laboratorium digunakan. Data diperoleh melalui pengisian angket/ kuesioner evaluasi pelaksanaan diklat kepada peserta. Validitas dan reabilitas instrumen telah diuji sehingga istrumen dapat digunakan dengan valid dan reliabel. Uji t dilakukan untuk mengetahui perbedaan nilai pengukuran sebelum dan sesudah laboratorium beroperasi. Hasil kajian menunjukkan bahwa semua indikator meningkat setelah operasionalisasi laboratorium di BDA. Secara statistik kepuasan peserta terhadap kelengkapan fasilitas pembelajaran dan keterampilan peserta meningkat signifikan. Adapun peningkatan pengetahuan peserta, peningkatan kepuasan peserta terhadap kelengkapan media pembelajaran dan peningkatan nilai hasil belajar peserta, secara statistik tidak meningkat signifikan.
\end{abstract}

Kata kunci: evaluasi, diklat, laboratorium, pemanfaatan, PHPI

\section{THE EVALUATION OF LABORATORY UTILIZATION ON FISH QUARANTINE OFFICERS TRAINING IN MARINE AND FISHERIES OFFICERS TRAINING CENTER, MINISTRY OF MARINE AFFAIRS AND FISHERIES}

\begin{abstract}
The laboratory become inseparable in Fish Quarantine Officer Training. Therefore, Marine and Fisheries Officers Training Center (MFO TC) in collaboration with Cirebon Fish Quarantine Office build the fish quarantine laboratorium in MFO TC campus in 2014. This study was conducted to evaluate the lab utilitazion by measure the change of training participans satisfaction in learning media and facilities, participans final grade, and cognitive/knowledge and psychomotor skill enhancement before and after laboratory operationalization. Data were collected by distributed the evaluation questionnaire. The instruments were used in this study valid and reliable according to the result of the instrument's validity and reability test. T-test two samples for means was used to analyse the differences of measurement before and after laboratory operationalization. Statistically, psychomotor skill enhancement and training participans satisfaction in facilities were significant increased after laboratory operationalization. Knowledge enhancement, training participans satisfaction in learning media and final grade were insignificant increased.
\end{abstract}

Keywords: fish quarantine officer, laboratory, evaluating, utilization, training

Permalink/DOI: http://dx.doi.org/ 10.21831/pep.v22i2.18458

Jurnal Penelitian dan Evaluasi Pendidikan ISSN 2338-6061 (online) 


\section{Pendahuluan}

Peningkatan kualitas sumber daya manusia masih menjadi prioritas pembangunan nasional (Presiden Republik Indonesia, 2015, p. 5). Pendidikan dan pelatihan (diklat) berperan penting dalam menghasilkan sumber daya manusia yang berkualitas, memiliki kompetensi keahlian dan berdaya saing, serta mempunyai karakter dan budi pekerti unggul. Sasaran dari kegiatan tersebut salah satunya adalah perbaikan mutu proses belajar mengajar di kelas dengan berorientasi pada setiap aspek perkembangan peserta diklat. Karena secara naluriah peserta diklat menginginkan pengalaman belajar yang konkret, menyenangkan, dan mencakup semua aspek kompetensi yang diperlukan. Pengalaman belajar dapat diperoleh melalui metode pembelajaran praktik di kelas maupun di luar kelas. Pembelajaran praktik merupakan suatu sistem pengajaran dengan memberikan materi pengajaran menggunakan peralatan seperti diperagakan dengan harapan peserta menjadi jelas menerima materi sekaligus memperoleh kesempatan untuk melaksanakan suatu pekerjaan sehingga mereka memiliki pengetahuan dan keterampilan serta bersikap sesuai dengan keterampilan tersebut (Fathurrahman \& Sutikno, 2007, p. 64). Ketersediaan sarana prasarana praktik yang berkualitas dan sesuai dengan standar menentukan keberhasilan tujuan pembelajaran dalam sebuah diklat.

Diklat perkarantinaan ikan baik fungsional maupun teknis sebagai salah satu kegiatan peningkatan kompetensi bagi petugas karantina ikan, sangat terkait erat dengan sarana dan prasarana yang dapat menunjang optimalisasi pencapaian tujuan pembelajaran. Tujuan pembelajaran dalam diklat ini dicapai melalui penyampaian teori dan praktik. Sesuai dengan kurikulum diklat perkarantinaan ikan, bobot penguasaan teori sebanyak 40 persen dan praktik 60 persen (Pusat Pelatihan Kelautan dan Perikanan, 2013, p. 8). Salah satu sarana yang diperlukan dalam pembelajaran diklat perkarantinaan ikan adalah ketersediaan fasilitas laboratorium dengan segala perlengkapannya sebagai penunjang kegiatan praktik bagi peserta diklat.
Dilihat dari fungsi idealnya, laboratorium menjadi tempat bagi pendidik/widyaiswara untuk mendalami konsep, mengembangkan metode pembelajaran, memperkaya pengetahuan dan keterampilan. Selain itu sebagai tempat bagi peserta diklat untuk belajar memahami materi melalui optimalisasi keterampilan proses serta mengembangkan sikap ilmiah. Fungsi laboratorium dalam posisi tersebut adalah sebagai tempat untuk memahami, membuktikan berbagai konsep dan melakukan penelitian ilmiah. Laboratorium sangat diperlukan dalam pembentukan sikap ilmiah peserta diklat. Dengan adanya laboratorium yang sesuai dengan standar, diharapkan peserta diklat mampu mengaplikasikan semua teori yang telah diajarkan dalam kelas.

Balai Diklat Aparatur (BDA) Kementerian Kelautan dan Perikanan (KKP) sebagai salah satu penyelenggara diklat bagi aparatur KKP bekerjasama dengan Stasiun Karantina Ikan Kelas II Cirebon membangun laboratorium uji karantina ikan sabagai sarana pendukung kegiatan kediklatan perkarantinaan ikan yang dilaksanakan di BDA KKP. Sejak diresmikan pada bulan Februari 2014, laboratorium uji karantina ikan BDA KKP telah digunakan sebagai tempat praktik pada Diklat Jabatan Fungsional Pengendali Hama dan Penyakit Ikan (PHPI) Tingkat Ahli dan Terampil dan Diklat Penjenjangan Jabatan Fungsional PHPI Tingkat Ahli dan Terampil. Sebelumnya, kegiatan praktik pada diklat PHPI sebagian besar dilaksanakan di dalam ruang kelas sementara untuk beberapa mata diklat tertentu, praktik dilakukan di Balai Uji Standar Karantina Ikan (BUSKI) yang berlokasi di Jakarta. Secara khusus laboratorium uji karantina ikan didirikan sebagai syarat akreditasi penyelenggaraan Diklat Dasar Jabatan Fungsional PHPI tingkat Ahli maupun Terampil. Akreditasi penyelenggaraan diklat menjadi suatu kebijakan penting dalam rangka menentukan kelayakan dalam penyelenggaraan program diklat, sehingga kemandirian pelaksanaan diklat lebih menjamin peningkatan kualitas diklat (Lembaga Administrasi Negara, 2017, p. 1). Akreditasi lembaga kediklatan, memberikan jaminan kepada ma- 
syarakat bahwa lembaga tersebut mampu dan kompeten melaksanakan kegiatan diklat secara profesional.

Keberadaan laboratorium dalam penyelenggaraan Diklat PHPI mempunyai peran strategis dalam meningkatkan pengetahuan, keterampilan dan sikap peserta diklat. Sehingga dalam rangka mengukur kemajuan pemanfaatan laboratorium uji karantina ikan BDA KKP pada kegiatan kediklatan PHPI maka evaluasi perlu dilakukan. Evaluasi program diklat merupakan proses untuk menjamin akuntabilitas dan peningkatan berkelanjutan (Edward, Scott, \& Raju, 2007, p. 4). Evaluasi kualitas pelaksanaan diklat dapat dilihat dari keseluruhan tahapan mulai dari persiapan, pelaksanaan serta dampak diklat terhadap peningkatan produktivitas kinerja layanan organisasi (Edward et al., 2007, p. 6). (Kirkpatrick \& Kirkpatrick, 2006, p. 21) mengemukakan model evaluasi melalui empat level yaitu level reaksi (reaction), pembelajaran (learning), perilaku (behavior), dan hasil (result). Pengukuran level reaksi dilakukan untuk mengetahui tingkat kepuasan peserta terhadap pelaksanaan program diklat; Pengukuran level pembelajaran dilakukan untuk mengetahui pencapaian pengetahuan, keterampilan dan sikap peserta setelah mengikuti diklat; Pada level perilaku, pengukuran dilakukan untuk mengetahui dampak diklat terhadap perubahan perilaku setelah peserta bekerja kembali ke instansi masing-masing; Sedangkan pengukuran level hasil dilakukan untuk mengetahui seberapa besar pengaruh program diklat terhadap kinerja instansi peserta (Kirkpatrick \& Kirkpatrick, 2006, pp. 21-26).

Level evaluasi yang berkaitan dengan ketersediaan laboratorium sebagai pendukung kegiatan diklat dan dapat diukur saat diklat berlangsung adalah level reaksi dan pembelajaran. Oleh karena itu kajian ini dibatasi pada bahasan pemanfaatan laboratorium terhadap level reaksi dan pembelajaran peserta Diklat PHPI. Hal ini dilakukan dengan mengukur perubahan level reaksi dan pembelajaran peserta Diklat PHPI sebelum dan sesudah laboratorium digunakan untuk kegiatan diklat. Level reaksi meliputi komponen kepuasan peserta dengan kriteria ke- puasan peserta terhadap ketersediaan media pembelajaran dan kepuasan terhadap kelengkapan fasilitas pembelajaran. Level pembelajaran meliputi komponen daya serap peserta terhadap meteri dengan kriteria nilai hasil belajar, serta peningkatan pengetahuan dan keterampilan peserta.

Berdasarkan latar belakang tersebut maka kajian ini bertujuan untuk mengevaluasi pemanfaatan laboratorium uji karantina ikan pada kegiatan diklat PHPI dengan (1) mengukur perubahan kepuasan peserta terhadap ketersediaan media pembelajaran dan kelengkapan fasilitas pembelajaran sebelum dan sesudah laboratorium digunakan; dan (2) Mengukur perubahan nilai hasil belajar, peningkatan pengetahuan dan keterampilan peserta sebelum dan setelah laboratorium digunakan.

\section{Metode Penelitian}

Kajian ini dilaksanakan di Balai Diklat Aparatur KKP Sukamandi, Jawa Barat pada Januari 2018. Kajian ini merupakan penelitian evaluatif yaitu penelitian yang mengetahui akhir dari sebuah kebijakan dalam rangka menentukan rekomendasi sebagai pertimbangan penentuan kebijakan selanjutnya (Arikunto \& Jabar, 2014, p. 59).

Subjek penelitian ini adalah populasi dari peserta Diklat Pengendali Hama dan Penyakit Ikan (PHPI) yang dilaksanakan sebelum dan sesudah laboratorium uji karantina ikan beroperasi. Secara keseluruhan terdapat 8 (delapan) angkatan yang terdiri dari 4 (empat) angkatan yang dilaksanakan sebelum operasional laboratorium dan 4 (empat) angkatan diklat yang dilaksanakan setelah operasionali laboratorium (Tabel 2).

Model yang dipakai dalam penelitian ini adalah model evaluasi Kirkpatrick. Model ini menggunakan 4 (empat) level evaluasi yaitu level reaksi (reaction), pembelajaran (learning), perilaku (behavior), dan hasil (result) (Kirkpatrick \& Kirkpatrick, 2006, p. 21).

Pengumpulan data hanya pada 2 (dua) level evaluasi yaitu level reaksi dan level pembelajaran karena level tersebut yang berkaitan dengan ketersediaan laboratorium dalam mendukung kegiatan diklat. Instrumen eva- 
luasi pada penelitian ini merupakan bagian dari pelaksanaan evaluasi penyelenggaraan diklat yang telah dilakukan secara kontinyu pada setiap diklat yang dilaksanakan BDA KKP. Instrumen telah dilakukan uji validitas isi yang melibatkan beberapa pakar dalam bidang evaluasi dan beberapa widyaiswara. Reabilitas instrumen atau keajegan instrumen diestimasi melalui penggunaan instrumen pada obyek yang sama dalam beberapa kali waktu yang berbeda (uji retest). Hasil uji menunjukkan bahwa tidak ada perbedaan signifikan pada penggunaan instrumen dalam waktu yang berbeda sehingga dapat dikatakan bahwa istrumen reliabel untuk digunakan sebagai alat ukur.

Komponen yang diukur pada instrumen level reaksi meliputi: (1) media pembelajaran dengan kriteria kepuasan peserta terhadap media pembelajaran; (2) fasilitas pembelajaran dengan kriteria kepuasan peserta terhadap fasilitas pembelajaran.
Data diperoleh dari pengisian angket/ kuesioner evaluasi peserta (responden) setelah mengikuti program Diklat PHPI. Data yang dikumpulkan berupa nilai pada kriteria kepuasan peserta terhadap media pembelajaran dan kepuasan peserta terhadap fasilitas pembelajaran dengan kategori sebagai sebagaimana tersaji pada Tabel 1 .

Tabel 1. Nilai dan Kategori pada Kriteria Evaluasi Pembelajaran

\begin{tabular}{cc}
\hline Nilai & Kategori \\
\hline $1-2$ & Tidak baik \\
$3-4$ & Kurang baik \\
$5-6$ & Cukup baik \\
$7-8$ & Baik \\
$9-10$ & Sangat baik \\
\hline
\end{tabular}

Sumber: (Pusat Pelatihan Kelautan dan Perikanan, 2013).

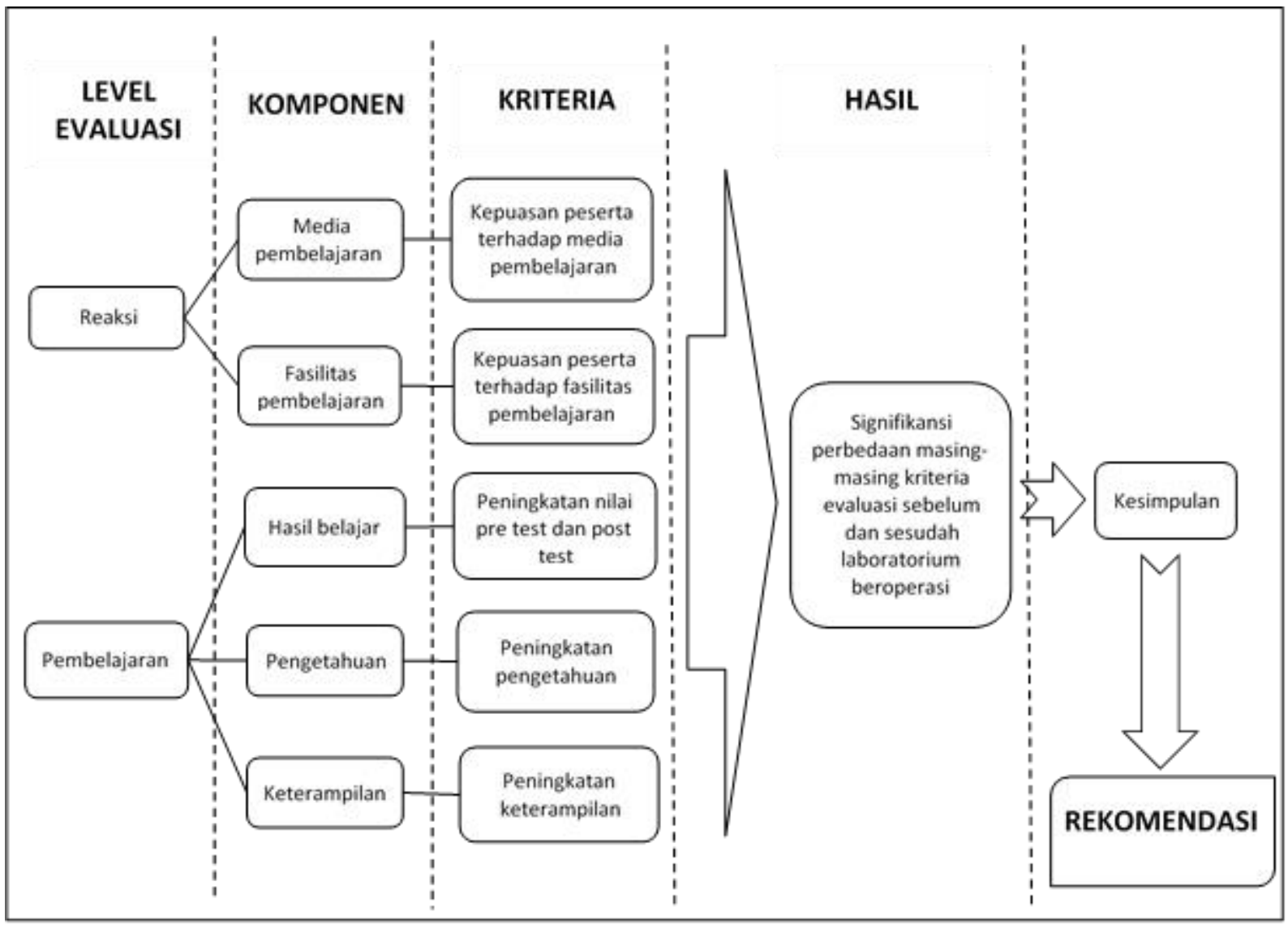

Gambar 1. Konstruk Umum Desain Penelitian 
Komponen yang diukur pada instrumen level pembelajaran adalah pengetahuan dan keterampilan yang meliputi: (1) hasil belajar peserta dengan kriteria peningkatan nilai pre-test dan post test peserta diklat; (2) pengetahuan dengan kriteria peningkatan pengetahuan peserta setelah mengikuti diklat; (3) keterampilan dengan kriteria peningkatan keterampilan peserta setelah mengikuti diklat.

Data peningkatan nilai pre-test dan post-test peserta diklat diperoleh dari nilai hasil peserta setelah mengerjakan test. Sedangkan untuk peningkatan pengetahuan dan keterampilan, data diperoleh dengan pengisian nilai pada angket/kuesioner evaluasi peserta setelah mengikuti program Diklat PHPI. Adapun kategorinya sebagaimana tersaji pada Tabel 1.

Teknik analisis data yang digunakan pada penelitian ini adalah kuantitatif deskriptif yaitu dengan menggambarkan fenomena yang ada berdasarkan hasil uji kuantitatif data yang diperoleh (Syamsuddin \& Damaianti, 2011, p. 14).

Secara teknis setelah responden mengisi angket/kuesioner evaluasi, nilai/skor dijumlahkan kemudian direratakan. Khusus untuk kriteria peningkatan nilai hasil belajar peserta, data diperoleh dari selisih nilai pretest dan post-test. Kemudian dilakukan uji t untuk mengetahui signifikansi perbedaan nilai setiap kriteria sebelum dan sesudah operasional laboratorium.

Kesimpulan ditarik berdasarkan hasil uji kuantitatif signifikansi perbedaan setiap kriteria evaluasi sebelum dan setelah laboratorium beroperasi. Konstruk umum desain penelitian ini tersaji pada Gambar 1.

Data sekunder berupa kelengkapan fasilitas pembelajaran diperoleh dari daftar inventaris ruangan di BDA KKP. Informasi tentang berjalannya diklat serta evaluasi penyelenggaraan diklat, diperoleh dari laporan akhir panitia pelaksanaan Diklat PHPI.

Tabel 2. Kegiatan Diklat PHPI di BDA KKP sebelum dan sesudah Operasional Laboratorium.

\begin{tabular}{|c|c|c|c|c|}
\hline No & Nama diklat & Tanggal pelaksanaan & $\begin{array}{l}\text { Jumlah } \\
\text { peserta } \\
\text { (orang) }\end{array}$ & $\begin{array}{l}\text { Sebelum/ } \\
\text { sesudah } \\
\text { operasional } \\
\text { laboratorium }\end{array}$ \\
\hline 1 & $\begin{array}{l}\text { Diklat Dasar PHPI Tingkat Ahli Angkatan I } \\
\text { Tahun } 2013\end{array}$ & 26 Febr. - 11 Mar. 2013 & 39 & sebelum \\
\hline 2 & $\begin{array}{l}\text { Diklat Dasar PHPI Tingkat Ahli Angkatan II } \\
\text { Tahun } 2013\end{array}$ & 14 - 26 Mar. 2013 & 40 & sebelum \\
\hline 3 & $\begin{array}{l}\text { Diklat Dasar PHPI Tingkat Terampil Angkatan I } \\
\text { Tahun } 2013\end{array}$ & 26 Febr. - 9 Mar. 2013 & 39 & sebelum \\
\hline 4 & $\begin{array}{l}\text { Diklat Dasar PHPI Tingkat Terampil Angkatan II } \\
\text { Tahun } 2013\end{array}$ & 14 - 25 Mar. 2013 & 40 & sebelum \\
\hline 5 & $\begin{array}{l}\text { Diklat Penjenjangan PHPI Tingkat Keahlian Muda } \\
\text { Angkatan I Tahun } 2014\end{array}$ & $9-17$ Sept. 2014 & 40 & sesudah \\
\hline 6 & $\begin{array}{l}\text { Diklat Penjenjangan PHPI Tingkat Keahlian Muda } \\
\text { Angkatan II Tahun } 2014\end{array}$ & $16-24$ Sept.2014 & 40 & sesudah \\
\hline 7 & $\begin{array}{l}\text { Diklat Penjenjangan PHPI Tingkat Keterampilan } \\
\text { Mahir Angkatan I Tahun } 2014\end{array}$ & 7 - 13 Okt. 2014 & 42 & sesudah \\
\hline 8 & $\begin{array}{l}\text { Diklat Penjenjangan PHPI Tingkat Keterampilan } \\
\text { Mahir Angkatan II Tahun } 2014\end{array}$ & $14-20$ Okt. 2014 & 37 & sesudah \\
\hline
\end{tabular}




\section{Hasil Penelitian dan Pembahasan}

\section{Gambaran umum}

Diklat bagi Jabatan Fungsional PHPI yang dilaksanakan di BDA KKP meliputi Diklat Dasar PHPI dan Diklat Penjenjangan PHPI. Diklat dasar maupun diklat penjenjangan terdiri dari diklat tingkat ahli dan terampil sesuai dengan jabatan peserta sebagaimana diatur dalam Peraturan Menteri Pendayagunaan Aparatur Negara dan Reformasi Birokrasi Nomor 22 Tahun 2010 tentang Jabatan Fungsional Pengendali Hama dan Penyakit Ikan dan Angka Kreditnyan. Diklat Jabatan Fungsional PHPI bertujuan untuk meningkatkan kompetensi PHPI agar mampu mengetahui karakteristik tugas, berwawasan luas, profesional dan bertanggung jawab sehingga dapat mendukung pelaksanaan tugas dalam mewujudkan visi dan misi organisasi di unit kerja masing-masing (Menteri Negara Pendayagunaan Aparatur Negara dan Reformasi Birokrasi, 2010, p. 25). Selain itu penyelenggaraan Diklat Jabatan Fungsional PHPI memfasilitasi peserta untuk mendapatkan sertifikat yang digunakan sebagai syarat kenaikan jenjang karier bagi Pejabat Fungsional PHPI.

Kurikulum diklat terdiri dari mata diklat yang dikelompokkan menjadi kelompok kompetensi umum, kompetensi inti dan kompetensi penunjang. Kompetensi umum adalah kompetensi yang berisi wawasan aspek pengetahuan dalam hal kebijakan, moti- vasi dan perilaku. Kompetensi inti adalah kompetensi teknis yang berkaitan langsung dengan tugas jabatan PHPI. Sedangkan kompetensi penunjang adalah kompetensi yang bertujuan menambah dan melengkapi wawasan terkait dengan tugas jabatan PHPI. Setiap kelompok kompetensi mempunyai jenis mata diklat dan jumlah jam pelajaran yang berbeda, namun secara umum bobot praktik pada Diklat PHPI lebih banyak dibandingkan bobot teori. Secara detail jumlah jam pelajaran pada Diklat Dasar dan Penjenjangan PHPI disajikan pada Tabel 3.

Pejabat Fungsional PHPI mempunyai tugas, tanggung jawab, wewenang dan hak secara penuh untuk melakukan pengendalian hama dan penyakit ikan serta lingkungan. Pengendalian hama dan penyakit ikan diartikan sebagai upaya untuk mencegah penyebaran, mempersempit/memperkecil area atau daerah tertular, area atau daerah wabah, dan menekan kerugian yang ditimbulkan akibat serangan hama penyakit ikan. Melalui upaya ini, hama penyakit ikan yang timbul di kawasan budidaya dapat ditanggulangi, begitu pula dengan hama dan penyakit ikan yang terbawa saat terjadi lalu lintas media/ komoditas. Melihat tugas pokok dan fungsi (tupoksi) PHPI yang berkaitan langsung dengan pemeriksaan hama dan penyakit ikan, maka ketersediaan sarana penunjang kegiatan praktik menjadi bagian yang tidak terpisahkan dari kegiatan diklat sebagai upaya peningkatan profesionalisme PHPI.

Tabel 3. Jumlah Jam Pelajaran pada Diklat PHPI

\begin{tabular}{|c|c|c|c|c|c|c|c|c|}
\hline \multirow{3}{*}{ No } & \multirow{3}{*}{ Diklat } & \multicolumn{6}{|c|}{$\begin{array}{l}\text { Jumlah Jam Pelajaran pada } \\
\text { Kelompok Kompetensi }\end{array}$} & \multirow[t]{3}{*}{ Jumlah } \\
\hline & & \multicolumn{2}{|c|}{ Umum } & \multicolumn{2}{|c|}{ Inti } & \multicolumn{2}{|c|}{ Penunjang } & \\
\hline & & $\mathrm{T}$ & $\mathrm{P}$ & $\mathrm{T}$ & $\mathrm{P}$ & $\mathrm{T}$ & $\mathrm{P}$ & \\
\hline 1 & Diklat Dasar PHPI Tingkat Ahli & 8 & 0 & 32 & 61 & 4 & 4 & 109 \\
\hline 2 & Diklat Dasar PHPI Tingkat Terampil & 6 & 0 & 26 & 53 & 4 & 4 & 93 \\
\hline 3 & Diklat Penjenjangan PHPI Tingkat Keahlian Muda & 4 & 0 & 16 & 48 & 4 & 8 & 80 \\
\hline 4 & Diklat Penjenjangan PHPI Tingkat Keterampilan Mahir & 4 & 0 & 16 & 36 & 4 & 4 & 64 \\
\hline
\end{tabular}

Keterangan:

$\mathrm{T}=$ teori

$\mathrm{P}=$ praktik 
Wallace (1991, p. 52) menyampaikan bahwa terdapat dua sumber pengetahuan yaitu pengetahuan yang diperoleh melalui belajar (received knowledge) dan pengetahuan yang diperoleh melalui pengalaman (experiential knowledge). Kedua sumber pengetahuan tersebut merupakan unsur kunci bagi pengembangan profesionalisme. Setiap peserta pelatihan membawa pengetahuan dan pengalaman ketika memasuki diklat baru. Efektifnya pelatihan tergantung pada bagaimana peserta pelatihan melakukan refleksi mengaitkan antara pengetahuan dan pengalaman serta praktik untuk memperbaiki pembelajarannya lebih lanjut (Wallace, 1991, p. 55). Kemampuan melakukan refleksi dari praktik yang didasarkan pada pengalaman dan pengetahuan menentukan pencapaian kompetensi profesional. Pendekatan utama dalam pembelajaran diklat khususnya bagi Jabfung PHPI adalah pendekatan praktik sehingga peserta mampu menemukan sendiri, melalui langkah-langkah kerja ilmiah, seperti mengamati, mengumpulkan data, mengukur, memaknai data dan menarik kesimpulan. Pertimbangan tersebut kemudian dituangkan dalam kurikulum sehingga jumlah jam pelajaran kompetensi inti mempunyai porsi pembelajaran praktik paling banyak dibandingkan dengan kelompok kompetensi yang lain. Selain itu kompetensi inti juga sangat berkaitan dengan hal-hal teknis yang menyangkut tupoksi Pejabat Fungsional PHPI.

Pembelajaran orang dewasa akan lebih efektif jika peserta lebih banyak terlibat langsung dibandingkan hanya pasif menerima dari pengajar (Kolb, 1984, p. 300). Praktik di laboratorium merupakan upaya untuk memberi kesempatan kepada peserta mendapatkan pengalaman langsung. Ide dasar belajar berdasarkan pengalaman mendorong peserta pelatihan untuk merefleksi atau melihat kembali pengalaman-pengalaman yang mereka pernah alami. Peranan laboratorium pada kegiatan kediklatan merupakan bagian dari proses belajar-mengajar berupa kegiatan praktik yang obyeknya sesuai dengan kurikulum yang tersedia. Kegiatan praktik pada Diklat Dasar PHPI meliputi praktik persiapan pelaksanaan kegiatan pengendalian
Hama dan Penyakit Ikan (HPI)/Hama dan Penyakit Ikan Karantina (HPIK), identifikasi HPI/HPIK golongan parasit, cendawan dan bakteri. Sedangkan untuk praktik pada Diklat Penjenjangan Jabatan Fungsional PHPI meliputi praktik penyiapan tempat, alat dan bahan laboratorium serta praktik pelaksanaan pengendalian HPI.

Pemanfaatan Laboratorium terhadap Peningkatan Kepuasan Peserta pada Media Pembelajaran

Berdasarkan pengukuran evaluasi kepuasan peserta terhadap kelengkapan media pembelajaran, diperoleh hasil bahwa terjadi kenaikan kepuasan setelah laboratorium uji karantina ikan digunakan sebagai sarana praktik kegiatan diklat (Gambar 2). Namun kenaikan tersebut secara statistik tidak signifikan (Tabel 4). Hal ini berarti keberadaan laboratorium tidak begitu bermanfaat terhadap peningkatan kepuasan peserta terhadap kelengkapan media pembelajaran.

Hal ini mungkin dikarenakan ketersediaan alat uji pemeriksaan sebagai sarana pembelajaran belum lengkap. Laboratorium hanya menyiapkan media praktik untuk pemeriksaan parasit, sementara untuk pemeriksaan bakteri, jamur/cendawan dan virus belum tersedia. Pembelajaran praktik untuk materi pemeriksaan bakteri dan cendawan terbatas pada penyiapan media tanam untuk kultur. Sedangkan identifikasi cendawan dan bakteri disampaikan secara teori melalui buku identifikasi. Media pembelajaran didefinisikan sebagai sarana yang dipakai untuk menyampaikan informasi dalam perspektif belajar mengajar sehingga tercapai pembelajaran yang efektif (Naz \& Akbar, 2008, p. 35). Media pembelajaran bermanfaat untuk mendukung pembelajaran dan membantu memahami sebuah pengetahuan (Kozma, 1991, p. 205). Media pembelajaran yang dirancang dengan benar, akan memberikan implikasi pada proses pembelajaran berupa efektifitas waktu, peningkatan minat peserta, klarifikasi gagasan, memperkuat konsep, mempertahankan memori, serta membantu membuktikan sebuah teori (Mohan, McGregor, Saunders, \& Archee, 1997). 
Tabel 4. Hasil Uji T dan Rerata Nilai Kepuasan Peserta terhadap Ketersediaan Media Pembelajaran sebelum dan sesudah Laboratorium Beroperasi

\begin{tabular}{cccccc}
\hline Diklat & $\begin{array}{c}\text { Rerata nilai } \\
\text { indikator }( \pm \text { SD })\end{array}$ & $d f$ & $P$ & thitung & Keterangan \\
\hline $\begin{array}{c}\text { Sebelum } \\
\text { Sesudah }\end{array}$ & $\begin{array}{c}7,323 \pm 0,366 \\
7,357 \pm 0,335\end{array}$ & 4 & 0,464 & 0,095 & Tidak berbeda signifikan $(\alpha=0,05)$ \\
\hline
\end{tabular}

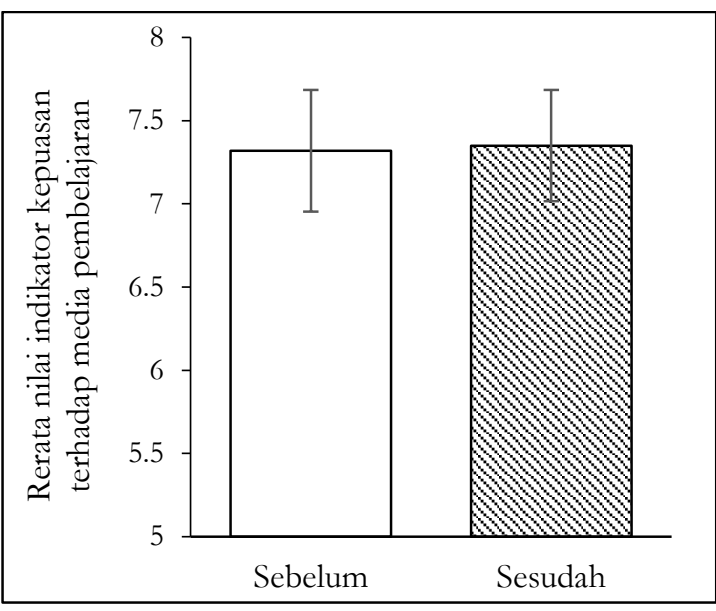

Gambar 2. Grafik Rerata Nilai

Kepuasan Peserta terhadap Media

Pembelajaran sebelum dan sesudah

Laboratorium Beroperasi

Faktor yang menentukan efektifitas media pembelajaran adalah bagaimana media mampu membantu memfasilitasi peserta untuk terlibat aktif dalam proses pembelajaran (Killen, 2003, p. 19). Keterlibatan peser-ta dalam proses pembelajaran akan terlihat jelas saat peserta sedang mengerjakan tugas, fokus pada isu penting dan secara sadar berusaha untuk serius dalam belajar (Killen, 2003, p. 19). Dampak penggunaan media pembelajaran dapat meningkat dengan menerapkan beberapa prinsip yaitu ketepatan pemilihan media yang relevan, keterkaitan media dengan materi sebelumnya dan hubungannya dengan tujuan yang akan dicapai pada pembelajaran sekarang, kesempatan untuk mendapatkan umpan balik dari peserta, dan evaluasi penggunaan media (Heinich, Molenda, Russell, \& Smaldino, 1996, p. 318). Agar pengalaman belajar peserta lebih konkret dan realistis, maka pengajar harus menggunakan dan menyiapkan media yang spesifik. Media pembelajaran membantu pengajar untuk mengklarifikasi, menetapkan dan mengkorelasikan konsep peserta didik. Media pembelajaran juga membantu mengajarkan konsep abstrak dengan cara yang nyata (Naz \& Akbar, 2008, p. 38). Penggunaan berbagai media pengajaran telah berhasil mengubah paradigma pembelajaran tradisional, dimana pengajar melakukan sebagian besar komunikasi searah dan para peserta adalah pendengar pasif, ke dalam pusat pembelajaran partisipatif yang memfasilitasi pembelajaran agar lebih produktif (Thomas, 2008, p. 106).

Melihat hasil kajian dan beberapa konsep tersebut diatas maka kelengkapan media pembelajaran dalam laboratorium menjadi hal yang cukup penting untuk mencapai tujuan Diklat PHPI. Ketersedian media pembelajaran yang lengkap juga berpotensi memberikan kepuasan bagi peserta diklat. Ketercapaian kepuasan mendorong peserta untuk menyerap materi dengan maksimal.

Pemanfaatan Laboratorium terhadap Peningkatan Pengetahuan Peserta Diklat

Berdasarkan hasil kajian, terjadi peningkatan pengetahuan peserta terhadap materi pembelajaran setelah laboratorium uji dioperasikan untuk kegiatan diklat (Gambar 3). Namun rerata peningkatan tersebut secara statistik tidak signifikan (Tabel 5). Sehingga dapat diartikan bahwa keberadaan laboratorium secara umum belum begitu bermanfaat terhadap peningkatan pengetahuan peserta diklat. 
Tabel 5. Hasil Uji t dan Rerata Nilai Indikator Meningkatnya Pengetahuan terhadap Materi Pembelajaran sebelum dan sesudah Laboratorium Beroperasi

\begin{tabular}{rccccc}
\hline Diklat & Rerata nilai indikator $( \pm \mathrm{SD})$ & $d f$ & $P$ & thitung & Keterangan \\
\hline $\begin{array}{l}\text { Sebelum } \\
\text { Sesudah }\end{array}$ & $7,583 \pm 0,330$ & 4 & 0,096 & 0,168 & $\begin{array}{c}\text { Tidak berbeda } \\
\text { signifikan }(\mathbf{a}=0,05)\end{array}$ \\
\hline
\end{tabular}

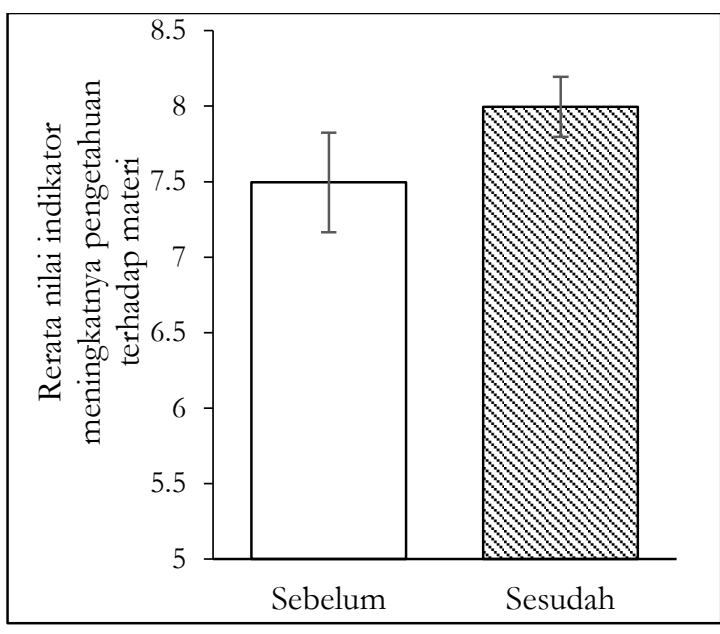

Gambar 3. Grafik Rerata Peningkatan Pengetahuan sebelum dan sesudah Laboratorium Beroperasi

Peningkatan pengetahuan secara efektif diperoleh dari kegiatan di kelas seperti diskusi, penyampaian teori, presentasi, pembelajaran berbasis masalah (problem based learning), seminar dan tanya jawab dengan para ahli (Kasilingam, Ramalingam, \& Chinnavan, 2014, p. 28). Sedangkan praktik dalam laboratorium efektif dalam meningkatkan keterampilan/psikomotorik. Sehingga keberadaan laboratorium sebagai sarana praktik kurang begitu berdampak terhadap peningkatan pengetahuan/kognitif peserta.

Ranah pengetahuan/kognitif merupakan salah satu dari tiga ranah kompetensi yang harus dimiliki peserta dalam menjalankan tugas profesionalismenya. Ranah yang lain adalah keterampilan/psikomotorik dan sikap kerja/afektif (Bloom, 1956, p. 7). Pengetahuan/kognitif didefinisikan sebagai pengenalan dan pengembangan dari kemampuan keterampilan intelektual (Bloom, 1956, p. 7). Ranah pengetahuan/kognitif berfokus pada kemampuan intelektual peserta. Hasil atau produk yang terkait dengan pengetahuan/kognitif adalah (Bloom, 1956, p. 18) (a) pengetahuan atau kemampuan untuk mengenali atau mengingat informasi; (b) pemahaman atau kemampuan untuk menunjukkan pemahaman dengan menggambarkan; (c) penerapan informasi pembelajaran untuk memecahkan masalah atau menjawab pertanyaan; (d) menganalisis atau membedah suatu masalah menjadi bagian penyusunnya; (e) mengevaluasi atau menilai sebuah gagasan dengan menggunakan kriteria eksplisit; dan (f) menciptakan atau menata ulang pengetahuan menjadi sebuah pola baru. Melihat teori diatas, pengetahuan/kognitif masih dalam bentuk yang abstrak artinya belum teraktualisasikan dalam perbuatan fisik. Pengetahuan kemudian diimplementasikan dalam bentuk keterampilan/psikomotorik.

Pemanfaatan Laboratorium terhadap Peningkatan Keterampilan Peserta Diklat

Berdasarkan hasil kajian, terjadi kenaikan yang signifikan rerata nilai indikator peningkatan keterampilan peserta diklat setelah laboratorium beroperasi (Gambar 4). Meskipun kenaikan hanya 0.357 namun kenaikan tersebut secara statistik berbeda nyata sebelum dan setelah operasionalisasi laboratorium (Tabel 6). Dengan demikian dapat diartikan bahwa keberadaan laboratorium bermanfaat dalam meningkatkan keterampilan/psikomotorik bagi peserta diklat.

Keterampilan praktis peserta didik di laboratorium dikaitkan dengan ranah psikomotorik. Keterampilan/psikomotorik berkaitan dengan kemampuan fisik seperti kecepatan, ketangkasan, akurasi, penggunaan instrumen, gerakan ekspresif dan penggunaan anggota tubuh (Simpson, 1966, p. 11). Menurut Zaghloul (2001, p. 3), pikiran dan tubuh manusia terhubung bersama saat melakukan aktivitas fisik. Produk yang berkaitan dengan keterampilan/psikomotorik adalah: 
Tabel 6. Hasil Uji t dan Rerata Nilai Indikator Meningkatnya Keterampilan terhadap Materi Pembelajaran sebelum dan sesudah Laboratorium Beroperasi

\begin{tabular}{rccccc}
\hline Diklat & Rerata nilai indikator $( \pm$ SD $)$ & $d f$ & $P$ & t hitung & Keterangan \\
\hline Sebelum & $7,450 \pm 0,275$ & \multirow{2}{*}{4} & 0,043 & 2,258 & $\begin{array}{c}\text { Berbeda signifikan } \\
(\mathbf{a}=0,05)\end{array}$ \\
Sesudah & $7,807 \pm 0,165$ & & & & \\
\hline
\end{tabular}

(a) persepsi, yaitu mampu mendeteksi isyarat untuk bertindak; (b) respon, yaitu mampu melakukan tindakan nyata; (c) mekanisme atau kemampuan untuk melakukan tugas tanpa pengawasan; (d) respon yang kompleks, atau kemampuan untuk menyusun pola aksi yang kompleks; (e) adaptasi, atau kemampuan untuk mengubah tindakan untuk merespons situasi baru; dan (f) originasi, atau kemampuan untuk mengembangkan tindakan baru yang original (Simpson, 1966, pp. 25-30).

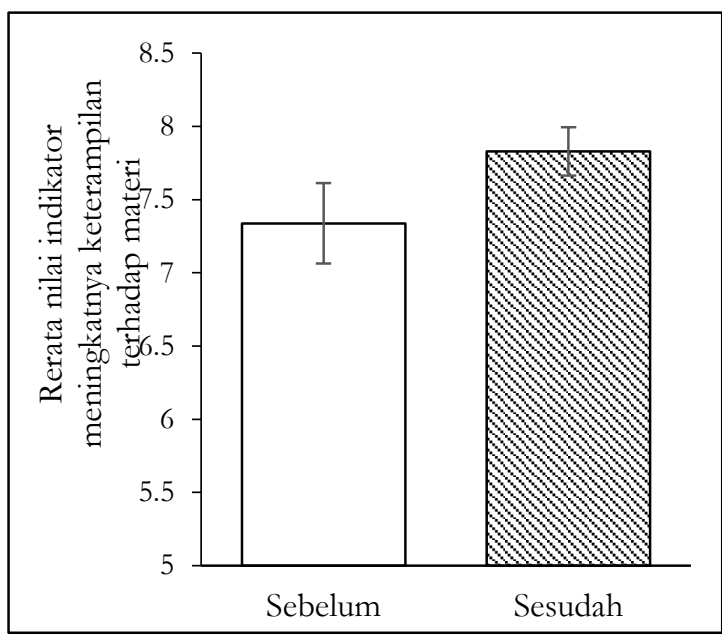

Gambar 4. Grafik Rerata Peningkatan

Keterampilan sebelum dan sesudah Laboratorium Beroperasi

Keterampilan (psikomotorik) dapat diperoleh melalui kegiatan praktik laboratorium, kursus kejuruan, pelatihan menggunakan peralatan tertentu (Kasilingam et al., 2014, p. 29). Kemampuan keterampilan/ psikomotorik secara efektif dapat diobservasi melalui demonstrasi atau simulasi. Simulasi membantu peserta untuk mempelajari langkah-langkah dari suatu pekerjaan. Dengan demikian peningkatan keterampilan peserta diklat mampu ditingkatkan melalui kegiatan praktik berupa demonstrasi dan simulasi di laboratorium.

Metode paling efektif untuk mengajar peserta didik melakukan sesuatu adalah dengan meminta mereka melakukan tugasnya (Schank, Berman, \& Macpherson, 1999, p. 235). Melalui praktik di laboratorium, peserta didik belajar dengan mempraktikkan keterampilan yang tidak bisa dipelajari secara teoritis. Saat melakukan praktik di laboratorium, peserta memiliki kesempatan untuk mengembangkan dan melatih keterampilan praktis dan keterampilan langsung mereka (Hunter, Mccosh, \& Wilkins, 2003, p. 73; Krivickas \& Krivickas, 2007, p. 196). Selain itu, praktik di laboratorium juga mampu mengembangkan kemampuan lain seperti keterampilan penulisan laporan, keterampilan kerja tim dan komunikasi saat melakukan eksperimen di laboratorium (Krivickas \& Krivickas, 2007, p. 191). Kegiatan praktik di laboratorium mampu menambah keterampilan praktis bagi para peserta dan memaparkannya kedalam bidang pekerjaannya yang relevan (Salim, Puteh, \& Daud, 2012, p. 546). Tupoksi petugas PHPI tidak bisa dilepaskan dari kegiatan di laboratorium. Pemeriksaan penyakit ikan dilakukan oleh petugas PHPI dalam skala lapangan maupun laboratorium. Oleh karena itu kegiatan praktik diperlukan bagi peserta diklat PHPI agar terbiasa dengan alat yang digunakan dalam pelaksanaan tugasnya di laboratorium.

Pemanfaatan Laboratorium terhadap Peningkatan Kepuasan pada Fasilitas Pembelajaran

Berdasarkan pengukuran evaluasi kepuasan peserta terhadap kelengkapan fasilitas pembelajaran, diperoleh hasil bahwa terjadi kenaikan kepuasan yang signifikan 
setelah laboratorium digunakan sebagai sarana praktik kegiatan diklat (Gambar 5). Uji t menunjukkan perbedaan nyata nilai indikator kepuasan peserta sebelum dan setelah laboratorium beroperasi (Tabel 7). Hal ini berarti keberadaan laboratorium bermanfaat dalam menaikkan kepuasan peserta terhadap fasilitas pembelajaran.

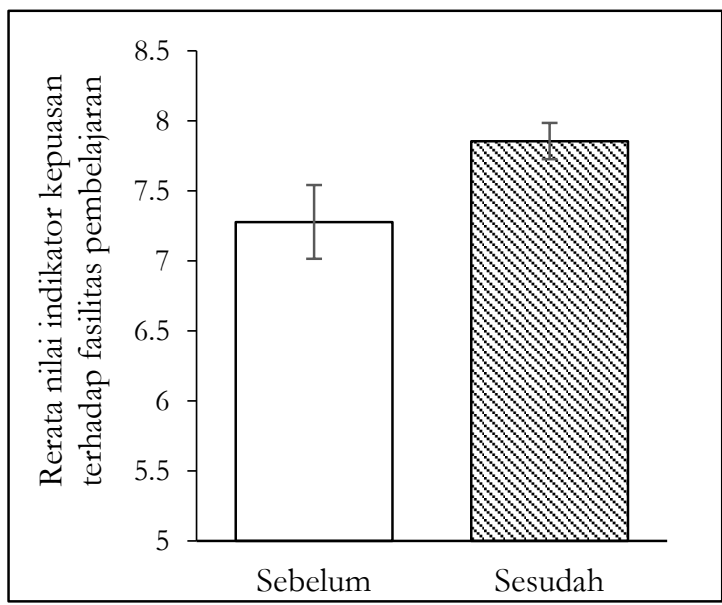

Gambar 5. Grafik Rerata Nilai

Kepuasan Peserta terhadap Fasilitas

Pembelajaran sebelum dan sesudah Laboratorium Beroperasi

Kepuasan peserta PHPI terhadap fasilitas pembelajaran setelah adanya laboratorium cukup beralasan karena pada diklat sebelumnya (sebelum laboratorium beroperasi) mereka melaksanakan kegiatan praktik hanya di kelas. Sedangkan untuk praktik pelaksanaan pengendalian hama dan penyakit ikan berupa pengujian pestisida dan kontaminan, serologi serta molekuler dilaksanakan di Balai Uji Standar Karantina Ikan (BUSKI) yang berlokasi di Jakarta. Dengan dibangunnya laboratorium, beberapa aktifitas praktik mampu difasilitasi di BDA KKP sehingga waktu dan sumber daya yang ada bisa digunakan secara efektif.

Fasilitas pembelajaran merupakan hal penting untuk menyediakan lingkungan bagi percepatan peningkatan pengetahuan peserta (Fleming \& Storr, 1999, p. 235). Selain itu fasilitas pembelajaran menjadi penting karena memberikan kondisi dalam meningkatkan pengalaman belajar.

Studi oleh Fleming \& Storr (1999, p. 234) mengungkapkan bahwa kualitas fasilitas pembelajaran memberikan pengaruh besar terhadap pengalaman belajar peserta. Laboratorium uji karantina menjadi fasilitas untuk mengeksplorasi keterampilan belajar peserta diklat PHPI sehingga mampu menambah pengalaman belajar mereka.

\section{Pemanfaatan Laboratorium terhadap Peningkatan Nilai Hasil Belajar Peserta Diklat}

Terjadi peningkatan rerata nilai akhir peserta diklat sebesar 11.045 persen setelah laboratorium beroperasi (Gambar 6). Namun kenaikan tersebut secara statistik tidak signifikan (Tabel 8). Artinya bahwa keberadaan laboratorium tidak begitu berpengaruh terhadap kenaikan nilai hasil belajar peserta diklat. Hal ini mungkin disebabkan karena sebagian besar soal ujian akhir yang diberikan hanya mencakup pengukuran kemampuan pengetahuan/kognitif peserta saja. (Tabel 9).

Tabel 7. Hasil Uji t dan Rerata Nilai Kepuasan Peserta terhadap Fasilitas Pembelajaran sebelum dan sesudah Laboratorium Beroperasi

\begin{tabular}{rccccc}
\hline Diklat & Rerata nilai indikator $( \pm \mathrm{SD})$ & $d f$ & $P$ & t hitung & Keterangan \\
\hline $\begin{array}{l}\text { Sebelum } \\
\text { Sesudah }\end{array}$ & $7,278 \pm 0,264$ & 4 & 0,024 & 2.798 & $\begin{array}{c}\text { Berbeda signifikan } \\
(\mathbf{a}=0,05)\end{array}$ \\
\hline
\end{tabular}

Tabel 8. Hasil Uji t dan Rerata Persentase Peningkatan Nilai Peserta sebelum dan sesudah Laboratorium Beroperasi

\begin{tabular}{rccccc}
\hline Diklat & $\begin{array}{c}\text { Rerata } \% \text { peningkatan nilai } \\
\text { peserta }( \pm \text { SD })\end{array}$ & $d f$ & $P$ & thitung & Keterangan \\
\hline $\begin{array}{l}41,465 \pm 10,795 \\
\text { Sebelum }\end{array}$ & $52,510 \pm 24,379$ & 4 & 0,172 & 1,073 & $\begin{array}{c}\text { Tidak berbeda signifikan } \\
(\mathbf{a}=0,05)\end{array}$ \\
\hline
\end{tabular}


Tabel 9. Contoh Soal Ujian Akhir dari Beberapa Mata Diklat pada Diklat PHPI di BDA KKP

\begin{tabular}{|c|c|c|c|}
\hline No & Diklat & Mata Diklat & Contoh Soal \\
\hline \multirow[t]{8}{*}{1} & \multirow[t]{8}{*}{ Dasar PHPI Ahli } & $\begin{array}{l}\text { Persiapan Pelaksanaan Kegiatan } \\
\text { Pengendalian Hama dan Penyakit Ikan }\end{array}$ & $\begin{array}{l}\text { Ikan yang dixxx tidak dapat digunakan untuk } \\
\text { pemeriksaan ... }\end{array}$ \\
\hline & & $\begin{array}{l}\text { Identifikasi Jenis, Jumlah, dan Klasifikasi } \\
\text { Media Pembawa HPI/HPIK }\end{array}$ & $\begin{array}{l}\text { Apabila ikan xxx xxx mengalami xxx, maka sistem } \\
\text { xxx akan terganggu dan biasanya xxx xxx ikan } \\
\text { akan mengalami ... }\end{array}$ \\
\hline & & $\begin{array}{l}\text { Sistem Manajemen Mutu Laboratorium } \\
\text { Pengujian HPI/HPIK (ISO/IEC 17025) }\end{array}$ & $\begin{array}{l}\text { Sebuah xxx yang menjalankan prosedur xxx dan } \\
\text { pengendalian xxx dengan menjaga xxx dari xxx } \\
\text { xxx maupun tersebarnya xxx disebut ... }\end{array}$ \\
\hline & & $\begin{array}{l}\text { Pemeriksaan Klinis Media Pembawa } \\
\text { HPI/HPIK }\end{array}$ & $\begin{array}{l}\text { Apabila ikan mengalami gejala klinis xxx , maka } \\
\text { kemungkinan ikan mengalami ... }\end{array}$ \\
\hline & & $\begin{array}{l}\text { Pengambilan Sampel Media Pembawa } \\
\text { HPI/HPIK }\end{array}$ & $\begin{array}{l}\text { Media pembawa/ikan yang dijadikan sampel } \\
\text { untuk xxx diantaranya, kecuali ... }\end{array}$ \\
\hline & & Identifikasi HPI/HPIK Golongan Parasit & $\begin{array}{l}\text { Dibawah ini jenis parasit xxx yang tidak bisa } \\
\text { diwarnai adalah ... }\end{array}$ \\
\hline & & $\begin{array}{l}\text { Identifikasi HPI/HPIK Golongan } \\
\text { Cendawan }\end{array}$ & $\begin{array}{l}\text { Penyakit jamur yang hanya menginfeksi xxx adalah } \\
\text {... }\end{array}$ \\
\hline & & Identifikasi HPI/HPIK Golongan Bakteri & $\begin{array}{l}\text { Apabila ikan mengalami xxx, maka kemungkinan } \\
\text { ikan tersebut mengalami, kecuali ... }\end{array}$ \\
\hline \multirow[t]{6}{*}{2} & \multirow[t]{6}{*}{$\begin{array}{l}\text { Dasar PHPI } \\
\text { Terampil }\end{array}$} & $\begin{array}{l}\text { Persiapan pelaksanaan kegiatan pengendalian } \\
\text { HPI/HPIK }\end{array}$ & Yang dimaksud Persiapan xxx adalah ... \\
\hline & & $\begin{array}{l}\text { Persiapan pelaksanaan kegiatan pengendalian } \\
\text { HPI/HPIK tingkat laboratorium }\end{array}$ & Yang termasuk good laboratory faktor xxx adalah ... \\
\hline & & Pemeliharaan media pembawa HPI/HPIK & Komponen dasar pemeliharaan xxx adalah ... \\
\hline & & $\begin{array}{l}\text { Pengawasan lalulintas media pembawa } \\
\text { HPI/HPIK }\end{array}$ & $\begin{array}{l}\text { Berikut ini merupakan xxx yang sering } \\
\text { dilalulintaskan dengan status xxx xxx adalah ... }\end{array}$ \\
\hline & & $\begin{array}{l}\text { Pemeriksaan Dokumen Karantina dan } \\
\text { Persyaratan Lainnya }\end{array}$ & $\begin{array}{l}\text { Dalam penerbitan sertifikat xxx masih sering } \\
\text { terjadi adanya perbedaan dalam hal jumlah dan } \\
\text { jenis sebagaimana tertulis dalam sertifikat xxx } \\
\text { bahkan untuk jenis-jenis yang dilindungi, untuk } \\
\text { mengantisipasi hal tersebut dilakukan pemeriksaan } \\
\text { ulang sebelum keberangkatan. Sesuai ketentuan } \\
\text { xxx maka prosentase pemeriksaan adalah ... }\end{array}$ \\
\hline & & Perlakuan media pembawa HPI/HPIK & $\begin{array}{l}\text { Dibawah ini adalah kondisi sampel yang tidak } \\
\text { dapat digunakan untuk keperluan xxx kecuali ... }\end{array}$ \\
\hline \multirow[t]{6}{*}{3} & \multirow{6}{*}{$\begin{array}{l}\text { Penjenjangan PHPI } \\
\text { Tingkat Keahlian } \\
\text { Muda }\end{array}$} & Merencanakan pengendalian HPI/HPIK & Apa tujuan pemantauan daerah xxx? \\
\hline & & & \\
\hline & & $\begin{array}{l}\text { Menyiapkan tempat, alat, dan bahan } \\
\text { laboratorium }\end{array}$ & $\begin{array}{l}\text { Alat xxx yang digunakan untuk xxx harus } \\
\text { dikalibrasi besaran ... }\end{array}$ \\
\hline & & $\begin{array}{l}\text { Mengembangkan sistem manajemen } \\
\text { laboratorium uji HPI/HPIK }\end{array}$ & $\begin{array}{l}\text { Salah satu cara untuk xxx alat laboratorium, } \\
\text { dilakukan ... }\end{array}$ \\
\hline & & $\begin{array}{l}\text { Melaksanakan pengendalian hama dan } \\
\text { penyakit ikan }\end{array}$ & Jaminan mutu hasil xxx dilakukan dengan ... \\
\hline & & $\begin{array}{l}\text { Memahami peraturan perundangan tentang } \\
\text { pengendalian hama dan penyakit ikan }\end{array}$ & Ketentuan tentang xxx diatur dalam ... \\
\hline \multirow[t]{5}{*}{4} & \multirow{5}{*}{$\begin{array}{l}\text { Penjenjangan PHPI } \\
\text { Tingkat } \\
\text { Keterampilan Mahir }\end{array}$} & $\begin{array}{l}\text { Menyiapkan data bahan penyusunan rencana } \\
\text { kerja }\end{array}$ & $\begin{array}{l}\text { Di bawah ini manfaat dari data bulanan } \mathrm{xxx} \\
\text { adalah ... }\end{array}$ \\
\hline & & & \\
\hline & & $\begin{array}{l}\text { Menyiapkan tempat, alat, dan bahan } \\
\text { laboratorium }\end{array}$ & Sterilisasi ruang xxx dilakukan pada ... \\
\hline & & $\begin{array}{l}\text { Melaksanakan pengendalian hama dan } \\
\text { penyakit ikan }\end{array}$ & $\begin{array}{l}\text { Kegiatan pelabelan koleksi xxx meliputi data } \\
\text { berikut ini, kecuali ... }\end{array}$ \\
\hline & & $\begin{array}{l}\text { Memahami peraturan perundangan tentang } \\
\text { pengendalian hama dan penyakit ikan }\end{array}$ & $\begin{array}{l}\text { Sesuai dengan UU Nomor xxx jabatan xxx terdiri } \\
\text { dari ... }\end{array}$ \\
\hline
\end{tabular}




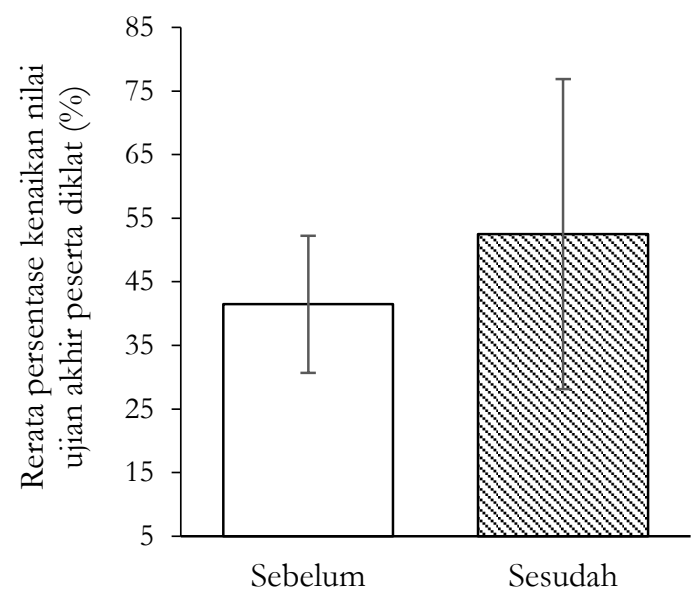

Gambar 6. Grafik Rerata Persentase

Peningkatan Nilai Ujian Akhir sebelum dan sesudah Laboratorium Beroperasi

Sesuai hasil kajian, peningkatan pengetahuan/kognitif peserta tidak signifikan dipengaruhi oleh keberadaan laboratorium. Beberapa studi diantaranya yang dilakukan oleh Hiltz \& Wellman (1997, p. 47) menyatakan bahwa nilai ujian akhir adalah hal yang umum digunakan untuk mengukur pencapaian kognitif peserta didik. Akan tetapi penggunaan nilai untuk pengukuran pencapaian pembelajaran tidak selalu memberikan hasil terbaik. Nilai ujian cenderung memiliki rentang pengukuran yang sangat terbatas dan hanya mencerminkan pencapaian pada ranah (kognitif, afektif dan psikomotorik) yang seragam. Selain itu, nilai memiliki sedikit hubungan dengan apa yang dipelajari peserta. Sebagai contoh, peserta mungkin sudah mengetahui materi sebelum mereka mengikuti diklat sehingga nilai peserta mungkin lebih terkait dengan partisipasi di kelas, penyerahan tugas tepat waktu, atau kehadiran dalam kelas. Selanjutnya, nilai mungkin bukan ukuran pembelajaran yang andal, terutama untuk tes kinerja, karena pengajar yang berbeda atau bahkan pengajar yang sama pada waktu yang berbeda cenderung tidak memberikan nilai secara konsisten. Oleh karena itu, dengan menggunakan nilai sebagai satusatunya ukuran pembelajaran dapat menimbulkan masalah, terutama saat mengukur hasil pembelajaran di berbagai diklat keterampilan. Pengembangan instrumen komprehensif yang mampu mengukur ketiga ranah pembelajaran akan lebih bermanfaat karena pembel- ajaran akan selalu melibatkan komponen kognitif, afektif, dan psikomotorik.

Peningkatan peran laboratorium untuk mengukur pencapaian pembelajaran peserta dapat dilakukan dengan ujian praktik yang dilaksanakan dengan memanfaatkan media pembelajaran di laboratorium. Pengukuran pencapaian pembelajaran peserta Diklat PHPI secara umum hanya dilakukan dengan tes tertulis pada akhir diklat. Oleh karena itu instrumen pengukuran seperti ujian praktek di laboratorium perlu ditambahkan agar pembelajaran peserta dapat terukur secara komperehensif.

\section{Simpulan}

Berdasarkan hasil penelitian dan pembahasan dapat disimpulkan bahwa pemanfaatan laboratorium uji karantina ikan di BDA KKP, secara rinci adalah: (1) ada perbedaan kepuasan peserta dan keterampilan peserta diklat dan kepuasan peserta terhadap kelengkapan fasilitas pembelajaran; (2) tidak ada perbedaan hasil belajar dan pengetahuan peserta terhadap materi pembelajaran antara sebelum dan sesudah laboratorium beroperasi.

Penambahan media pembelajaran di laboratorium perlu dilakukan dalam rangka peningkatan kepuasan peserta terhadap kelengkapan media pembelajaran. Selain itu perlu adanya instrumen pengukuran pencapaian peserta yang komperehensif sehingga ketiga ranah pembelajaran (kognitif, psikomotorik dan afektif) dapat dapat dievaluasi dengan baik.

\section{Daftar Pustaka}

Arikunto, S., \& Jabar, C. S. abdul. (2014). Evaluasi Program Pendidikan (2nd ed.). Jakarta: Bumi Aksara.

Bloom, B. S. (1956). Taxonomy of educational objective cognitive domain. New York: Longmans, Green and Co.

Edward, J. E., Scott, J. C., \& Raju, N. S. (2007). Evaluating human resources programs: A 6-phase approach for optimizing performance. San Fransisco: Pfeiffer.

Fathurrahman, P., \& Sutikno, S. (2007). 
Strategi belajar mengajar. Bandung: PT Refika Aditama.

Fleming, D., \& Storr, J. (1999). The impact of lecture theatre design on learning experience. Facilities, 17(7/8), 231-236. https://doi.org/10.1108/02632779910 270186

Heinich, R., Molenda, M., Russell, J., \& Smaldino, S. (1996). Instructional media and technologies for learning. Englewood Cliffs New Jersey: Prentice-Hall, Inc, Asimon \& Scuster Company.

Hiltz, S. R., \& Wellman, B. (1997). Asynchronous learning networks as a virtual classroom. Communications of the ACM, 40(9), 44-49. https://doi.org/10.1145/260750.2607 64

Hunter, C., Mccosh, R., \& Wilkins, H. (2003). Integrating learning and assessment in laboratory work. Chem. Educ. Res. Pract., 4(1), 67-75. https://doi.org/10.1039/B2RP90038 F

Kasilingam, G., Ramalingam, M., \& Chinnavan, E. (2014). Assessment of learning domains to improve student's learning in higher education. Journal of Young Pharmacists, 6(1), 27-33. https://doi.org/10.5530/jyp.2014.1.5

Killen, R. (2003). Effective teaching strategies: lessons from research \& practice. Melbourne: Thomson Social Science Press.

Kirkpatrick, D. L., \& Kirkpatrick, J. D. (2006). Evaluating training programs: the four levels (3rd ed.). San Francisco: Berret-Koehler Publisher, Inc.

Kolb, D. A. (1984). Experiential learning: experience as the source of learning and development. Englewood Cliffs, NJ: Prentice Hall.

Kozma, R. B. (1991). Learning with Media. Review of Educational Research, 61(2), 179-211. https://doi.org/10.3102/00346543061
002179

Krivickas, R. V., \& Krivickas, J. (2007). Laboratory instruction in engineering education. Global Journal of Engineering Education, 11(2), 191-196.

Lembaga Administrasi Negara. (2017). Petunjuk teknis akreditasi diklat. Jakarta: Pusat Pengembangan Program dan Pembinaan Diklat, Lembaga Administrasi Negara.

Menteri Negara Pendayagunaan Aparatur Negara dan Reformasi Birokrasi. Peraturan Menteri Negara Pendayagunaan Aparatur Negara dan Reformasi Birokrasi Nomor 22 Tahun 2010 tentang Jabatan Fungsional Pengendali Hama dan Penyakit Ikan dan Angka Kreditnya (2010).

Mohan, T., McGregor, H., Saunders, S., \& Archee, R. (1997). Communicating!: theory \& practice (4th ed.). Sydney: Harcourt Brace.

Naz, A. A., \& Akbar, R. A. (2008). Use of media for effective instruction its importance: some consideration. Journal of Elementary Education, 18(1-2), 35-40. Retrieved from http://pu.edu.pk/images/journal/JE E/PDF-Files/JEE-18(1-2) No_3.pdf

Presiden Republik Indonesia. Peraturan Presiden Republik Indonesia Nomor 2 Tahun 2015 tentang Rencana Pembangunan Jangka Menengah Nasional Tahun 2015 - 2019 (2015).

Pusat Pelatihan Kelautan dan Perikanan. (2013). Pedoman penyelenggaraan dik.lat PHPI. Jakarta: Pusat Pelatihan Kelautan dan Perikanan, Kementerian Kelautan dan Perikanan.

Salim, K. R., Puteh, M., \& Daud, S. M. (2012). Assessing students' practical skills in basic electronic laboratory based on psychomotor domain model. In International Conference on Teaching and Learning in Higher Education (ICTLHE) (pp. 546-555). 
Schank, R. C., Berman, T. R., \& Macpherson, K. A. (1999). Learning by doing. In C. M. Reigeluth (Ed.), Instructional-Design Theories and Model: $A$ New Paradigm of Instructional Theory 2 (pp. 161-175). New Jersey: Lawrence Erlbaum Associates.

Simpson, E. J. (1966). The classification of educational objectives: the psychomotor domain. Illinois Joumal of Home Economics, 10(4).

Syamsuddin, A. R., \& Damaianti, V. S. (2011). Metode penelitian pendidikan bahasa. Bandung: Remaja Rosdakarya.

Thomas, M. (2008). Effective teaching: a measure of excellence. New Delhi: S.Chand \& Company.

Wallace, M. (1991). Training foreign language teachers. Cambridge: Cambridge University Press.

Zaghloul, A.-R. M. (2001). Assessment of lab work: A three-domain model; cognitive, affective and psychomotor. In ASEE Annual Conference \& Exposition. Albuquerque. 